been influenced by the ones that Paul was then writing and that he read to Goll.

I never said or implied that Goll accused his new friend of plagiarism. He was dead when Claire, his wife, made this accusation.

My essay, moreover, is not a study of the relation between these two poets but a reflection on the very different, more general question of plagiarism in poetry.

Yvan Goll was not unknown to me when he visited me in 1949. I had Le nouvel Orphée (1923) in my library. I just didn't know anything about his recent life.

Yves Bonnefoy

Paris

\section{The Uses of Philology}

\section{To THE EDITOR:}

I've thought to myself on several occasions that it is a shame most academic journals do not set space aside for readers' letters. Perhaps few readers think to write a letter. The average reader of an academic journal-I prefer to think of myself as a scavenger-is an academic, so the appropriate response to an article would be to compose one's own and thereby demonstrate through detailed analysis where the article under consideration is deficient and supplement it with a superior reading. When said article is published a year or two later, people may even remember what the original article was about.

I write this letter to PMLA because it is everything an article ought not to be: hasty, immediate, a gut response, ill-conceived, angry, rash, and perhaps poorly argued. After reading the three articles and introduction in the cluster "Philology Matters" (125.2 [2010]: 283-336), I was left irritated and bewildered. I was irritated with how often philology has been rediscovered of late, even though philological methods (word study, historical linguistics, and textual criticism, to name a few) have been going strong and progressing in the work of numerous critics, many of whom might never identify themselves as philologists. Jerome McGann, Susan
Stewart, Anne Carson, Virginia Jackson, and N. Katherine Hayles spring to mind. McGann in particular has been at the forefront of theorizing new ways to relate textual criticism and editorial theory to literary interpretation (see esp. The Textual Condition and Radiant Textuality) and has been pulling his hair out over why this relation has yet to catch on more broadly (The Scholar's Art and The Point Is to Change It).

I'm bewildered over why these "rediscoveries" of philology are dead set on looking backward. The critics I mention above represent the foresight of philology and philological methods (e.g., their relevance to the so-called new media, their use of the materiality of texts to reconsider conceptions of genre), whereas the Romance philologists Michelle R. Warren trots out in her introduction, Erich Auerbach and Ernst Robert Curtius (though, curiously, not Leo Spitzer), represent philological hindsight. Even the more recent critics Warren invokes, Edward Said and Édouard Glissant, understand philology retrospectively, not as a means to develop novel modes of investigation and interpretation but as a way to bolster what they (and by a certain logic we) are already doing.

Nowhere is this more evident than in the thematic link Warren provides for the articles in the cluster: "the ways that they excavate and activate silence" (286). I had the privilege of sitting in on the dissertation defense of a friend and colleague of mine, Michael Kicey, who expressed the problem with excavations of silence more eloquently than I ever could. If I understood him correctly-and, as my letter's scatterbrained prose suggests, I may not have-the "gotcha" approach to discursive silences, be they in a literary text or in criticism, is fundamentally wrongheaded. "[T] o reconstruct what has been lost," as Warren says (284), is indeed prime philological territory, but the additional tendency to supplement those silences with rank conjecture simply reproduces the critical blindness for which oldschool philology comes under fire. Additionally, to point to a silence with a cheap Aha! is not productive. These silences are almost never grappled with as silences, as irrevocably lost, as 
lacunae (figurative or literal) never intended to be filled or explained. To treat silence as silence is ridiculously hard, because it would entail understanding how meaning is made (and unmade) in a space of absolute indeterminacy, where the only appropriate response is restraint: not to say or to say only provisionally. Carson's book of Sappho translations (If Not, Winter) is a decent but flawed example of how to go about doing this.

If what I have said here should strike you, O Benevolent Reader of our fair PMLA, as absurd, unfair, or irresponsible, remember that I am a nobody, no longer possessed of real academic privileges, unemployed, no one significant in any academic field or critical discourse, whose future career is up in the air. You may well never hear from me again.

Nicholas A. Theisen Ann Arbor, MI

\section{Writing for Lay Readers}

\section{To THE EDITOR:}

I had just received an e-mail from my former graduate school adviser asking if a young graduate student of his who had moved to my city could contact me for advice. Always happy to meet new people, I said yes. I soon received a pleasant e-mail from the student, who told me about her research interests, but as she began describing her project I could feel my eyes glaze over. Though she was discussing a research field that interests me, I was wearied by her diction: "heteronormative discourse," "problematizes," a rampant use of gratuitous quotation marks. Her writing was in danger of becoming a parody of itself. Why was she using this language to talk to me? It was so formal and tedious. And why my disappointment? Because this dry, almost calcified academic language does a disservice to our work as academics in the humanities. The typical academic will have little trouble decoding catchwords like "hegemonic" and "epistemological," but what about lay readers? That a young graduate student was using this language left me concerned. All fields have their jargon, but if graduate students are being trained merely to assemble prefabricated phrases lest they not be able to compete with the field's old guard, are clarity and accessibility being foreclosed from day one?

I have the great fortune of being a nontenured scholar. A strange assertion, perhaps, since securing a tenure-track position is often seen as the be-all and end-all of academic success. Though I have kept one foot in the academic world through adjunct teaching, presenting papers at conferences, publishing, and other academic tasks, I have made a satisfying career working in arts and cultural production outside academia. I have had the privilege of sharing my work with nonspecialized audiences and have tried to join a dying breed: the public intellectual. Whether offering lectures through the Pennsylvania Humanities Council, an organization that brings humanities experts to lay communities; running book groups at local libraries; or providing engaging programming through my job as director of arts and cultural programming at a Jewish community center, I have worked to foster learning, inquiry, and intellectual stimulation in ways that are hardly dumbed down or reductive.

But what of my colleagues in the ivory tower? I don't want to stereotype, since some academics are producing engaging, accessible scholarship. Happily, the age of high theory seems to have died, and much scholarly work nowadays is insightful and readable. Yet a tendency to write for a specialized audience persists, to our profession's detriment, perpetuating jargon-filled modes of communication that hamper the dissemination of important new ideas.

Ask academics in the humanities why they pursued their career, and, in addition to expressing a love of research or teaching, many will express a worthy desire to combat racism, sexism, homophobia, economic inequality, or another of the injustices plaguing society. Many of us want our work to be culturally relevant, yet we often feel forced to perform in obtuse or inflated language that our profession seems to demand if we want to be taken seriously by our peers. 